\title{
The Artistic Tradition: Moravia and Kandinsky
}

\section{Douglas Radcliff-Umstead}

To be an artist requires establishing a meaningful relationship with the world of objective reality. The Russian painter Wassily Kandinsky in his theoretical writings and the Italian author Alberto Moravia in his novel La noia (1960) have examined the problem of creativity and the artist's confrontation with a disturbing universe of material objects. Kandinsky remarks in his Reminiscences of 1913 that ever since childhood objects disturbed him; he would remember the colors of the visual field but not the objects in the visual world. The Russian artist records an early experience when he beheld a canvas placed upside-down and in the twilight he saw it only in terms of colors and forms without distinguishing what the canvas represented; Kandinsky concluded that objects spoiled his painting. ${ }^{1}$ The protagonist of Moravia's novel is the painter Dino who relates his life-long awareness of the nothingness that has surrounded his existence and has created a gulf between himself and the 'thingness' of physical objects. Even as a child Dino was not truly alive because his perpetual attention to objects brought about a spiritual paralysis and imprisoned him in a death-like recognition of the absurdity in the external world. The condition of boredom which gives the title to the Italian novel is a state of distraction and forgetfulness, an insufficiency or inadequacy of reality, a withering and loss of vitality, and above all "una malattia degli oggetti." 2 Dino's anguish arises from his inability to create on his own canvases that world of pure form and composition which Kandinsky considers to be the goal of all serious artists, and in the course of the novel the protagonist specifically refers to the Russian painter's theory on the challenge of creativity.

At the time the Italian narrative begins Dino is thirty-five. ${ }^{3} \mathrm{His}$ age is doubtlessly one of Moravia's many literary echoes, here to Dante's "nel mezzo del cammin di nostra vita"; and the Dantesque reference is re-enforced in the novel's exterior structuring 
into nine chapters with prologue and epilogue that recall the mystical number nine in the Vita nowa. Dino too expects to find a wondrous new life in the simulated poverty of an artist's career away from the asphyxiating environment of his mother's villa on the via Appia. Ten years before the start of his story Dino began his futile struggle to find a way out of noia by opening a studio on via Margutta. But instead of revealing himself as a mature adult in the midst of his life who must prepare himself for an enlightening experience of sin and redemption, the very un-Dantesque Dino remains in truth an arrested adolescent with his persistent reluctance to face the inadequacies of life in conventional society. The Moravian character lacks what Kandinsky calls the artist's essential personality which is an over-riding response to the principle of inner necessity to seek expression through creation.

Art as therapy for boredom proved to be for Dino only a means of evading reality inasmuch as he chose to be an abstractionist and thereby avoided the task of facing the real world. The slashing of a canvas which opens Dino's diary is an act of confession wherein Moravia's protagonist admits to ten years of bad faith: ". . . tutto ad un tratto, come per un'ispirazione finalmente autentica . . trinciai la tela che stavo dipingendo e non fui contento finché non l'ebbi ridotta a brandelli. . . . Subito dopo, però, mi accorsi che tutta la mia energia, come dire? creatrice, si era scaricata in quel furioso e, in fondo, razionale gesto di distruzione" (p. 5). The adjective autentica clearly reveals Dino's painful acknowledgement that in tearing the canvas to shreds he was destroying a worthless object. The slashed painting is replaced with the empty canvas that stands as the symbol of the protagonist's creative void and that has given the title The Empty Canvas to the novel's English translation. This empty canvas symbolizes the fully negative nature of Dino's career as an artist, for in ten years he has not accomplished anything of genuine worth. Moravia's protagonists, from Michele in the early novel Gli indifferenti of 1929 to Francesco Merighi of L'attenzione in 1965, struggle in vain against the enervating indifferenza, inattenzione and noia that characterize living in a society without authentic values. Violent confrontation with his own work of art compels Dino to recognize that he has not eluded the vulgarly materialistic values of a society which Kandinsky condemns as being without soul.

In the hope of sustaining the illusion that he might one day return to his canvas and succeed in representing a world of pure pictorial composition, Dino later expressly quotes a text by Kandinsky on the miraculousness of a blank canvas: " . . piena di 
tensioni, con mille voci sommessa, gravida di attesa. . . . Meravigliosa è la tela vuota . . . " (p. 154). Kandinsky's article "Toile Vide" first appeared in 1935 in Cahiers d'art at a moment in the Russian artist's career when he had arrived at a state of creative serenity to look beyond the emptiness of a virgin canvas and see the harmonious composition that awaited only the touch of the artist's brush:

An empty canvas, apparently really empty, that says nothing and is without significance. Almost dull, in fact. In reality, however, crammed with thousands of undertone tensions and full of expectancy. Slightly apprehensive lest it should be outraged. Yet docile enough. Ready to do what is required of it, and only asking for consideration. . . It riddles the visage of falsity pitilessly and raises her voice to a scream too shrill to be endured. . . .

Dino by attempting to lead a counterfeit career as an abstractionist painter committed repeated outrages against his canvases. A false vulgarian like his neocapitalistic mother, Dino at last could no longer endure the shrill scream of his canvases and furiously attacked his own work. The Moravian character never knows that "solemn calm of a creative artist" which Kandinsky declared to be the triumph of a painter achieving truthful form as the external expression of inner meaning. The true artist can hear the voice of an empty canvas that calls to him saying "Here I am!" For the creative artist there is no emptiness, for he beholds immediately the painting on the blank cloth. The process of painting is one of revelation to the artist who listens attentively as the canvas communicates its mysteries. Before he can touch the canvas' surface the artist must seek out an illusory space where the painting's action is to occur. Dino lacks the ability to submit to and respect the autonomy of an empty canvas, which becomes for him merely the ever-present symbol of sterility and alienation.

Moravia does not condemn abstract art in itself, for abstractionism may be the way for attaining a superior vision of reality behind distorted outer appearances. ${ }^{5}$ Over a long career with many moments of hesitation, experimentation and revaluations, Wassily Kandinsky reached that superior vision. The first stage of his career lasted until the outbreak of World War I and included fairytale landscapes, murky panoramas, Fauvist explorations in color, and esoteric allegories. This early period is characterized by a striving toward visionary creations throughout series of "Improvisations" and "Impressions" of actual scenes, culminating in large-scale non-objectivist "Compositions" so amorphous that 
they seem lacking in unified design. After the war Kandinsky became concerned with harmonious geometric structure, and the early canvases that he produced at the Bauhaus in Weimar during the mid-twenties show trapezoids, parallelograms, circles and squares floating across a neutral background. Having mastered carefully ordered design, the artist began during his tenure at the Dessau Bauhaus to reintroduce luminous color planes into his compositions. Kandinsky's discomfort with the world of physical object did not force him into abstractionism as a way of evasion; instead he moved away from visual referents to fashion a new world where point, line and color are organized in a controlled pattern that replaces the representation of actual objects. By the time of his final Parisian period of creativity (1933-1944) Kandinsky had so transcended his uneasiness before objects that in his late canvases humanoid figures appeared in a design which pulsated with the rhythms of Baroque liberation. The artist's early visionary theories are best expressed in his book Concerning the Spiritual in Art and Painting in Particular of 1911 while his later efforts to establish geometric boundaries for color are analyzed in the text Point and Line to Plane of 1926. Both in the theoretical writings and canvases Wassily Kandinsky was striving to elude the tyranny of the object and the mimetic tradition of art to achieve in painting a synthesis of music, science and philosophy. The Russian artist abandoned traditional form to create color symphonies with his own new, abstract forms.

Both Kandinsky and Moravia's protagonist admit that objects haunt them. Dino stares in amazement before objects like a drinking-glass whose being he cannot fathom. The theme of incomprehensibility must be associated with that of fragmentation, for the object-sickness of Moravia's protagonist prevents him from accepting the presence of intrinsic order in the material universe which he can view as only fragmented in its incoherent parts. When Dino examines an inanimate object like a canvas or a wineglass, noting all its details, he feels a steadily increasing dread at his inability to penetrate to the depths of the object. That failure to relate to an object triggers in Dino an impulse toward a violent act. By contrast Kandinsky never records an attitude of destructive rage toward objects. Although as a mature artist Kandinsky continued to believe that objects harmed his paintings, he never abandoned a tendency he had held since childhood to regard objects animistically. As a boy he used to feel everything 'dead' like cigarette stubs or buttons were trembling with an arcane life. In his adulthood the Russian painter persisted to cognize the world 
by perceiving life-like movements in objects. Kandinsky mentions in his autobiographical sketches how raindrops and oil-paints appeared to him as being roguish and playful:

On my palette sit high, round rain-drops, puckishly flirting with each other, swaying and quivering. Unexpectedly they unite and suddenly become thin, sly threads which disappear in amongst the colors, and mischieviously skip about and creep up the sleeves of my coat. . . As a thirteen- or fourteen-year-old boy I bought a box of oil-colors with pennies slowly and painfully saved. To this day I can still see those colors coming out of the tubes. One press of my fingers and jubilantly, festively, or grave and dreamy, or turned thoughtfully within themselves, the colors came forth. ...

The way Kandinsky attributes human traits to inanimate objects derives from a manner of viewing reality which psychologists have called "physiognomic perception." This form of perception, which can most commonly be found among children, primitive peoples, schizoids and occasionally artists, consists in the dynamization of things. ${ }^{7}$ Kandinsky's attitude toward objects thus differs fundamentally from Dino's alienation, for the Russian artist, rather than experiencing an insufficiency of reality, discovered in objects a superabundance of expressive life whose exuberant energy he tried to recapture in his canvases through the art of abstraction.

Dino displays none of Kandinsky's receptivity to external phenomena since the Moravian character has immured himself in his own precious boredom. The painter in the Italian novel is frequently guilty of trying to define objects and other persons with limiting terms, and when reality eludes him, Dino almost always reacts with violence. In what is a peculiarly Moravian manner of perceiving reality, Dino cognizes the universe erotically. The Italian painter would like to consider other persons as objects in search of an owner. He sometimes regards his mistress Cecilia as a fragile glass that he might shatter. The young woman is the one person who represents reality for Dino. On the day he first met Cecilia the painter signed his empty canvas as if to declare that he had definitively abandoned art. Dino would like to assume ownership of Cecilia and free himself of noia through total possession of the elusive reality embodied in his mistress. Through sexuality he hopes to move from the contingency of existence to the fullness of being. Communication through eros, however, does not prove to be a way to knowledge of the world of Dino, who finds Cecilia to be "inafferrabile" or "unseizable." In the hope of freeing 
himself from dependence on the young woman, Dino dreams of returning to the empty canvas and conquering its blankness: "Mi dissi che, se non altro, ove fossi riuscito a riempire in qualche modo la tela che tuttora campeggiava sul cavalletto, poi avrei avuto una ragione di piú per separarmi da Cecilia; sapevo, infatti, che soltanto la pittura avrebbe potuto colmare nella mia vita il vuoto che vi avrebbe lasciato la fine della nostra relazione" ( $p$. 153). It is at this moment that Dino comforts himself by reading Kandinsky's article on the wondrousness of an empty canvas. But it is not to the empty canvas that a suddenly creative Dino returns; instead he continues the pursuit of the nothingness which Cecilia incarnates.

The sterile inability of Moravia's protagonist to resume painting is expressed by the author with terms that usually signify erotic failure: impotente and impotenza. Recognizing that he lacks a drive toward creative realization of his artistic aspirations, Dino confuses art with eros by becoming the rival of Cecilia's first lover: the dead painter Balestrieri. For Kandinsky a painter like Balestrieri would have represented the very negation of art, for Cecilia's original lover prostituted painting by using his profession as a pretext for luring young models to his studio. Balestrieri was not only lacking in the true artist's sensitivity to the principle of inner necessity, but unlike Dino, he remained unaware of his deficiencies. Painting in an academically naturalistic style, Balestrieri never saw the lie behind his canvases and actually succeeded in sustaining the illusion that his pictures expressed an authentic relationship with a concrete and coherent world. Dino's envy of Balestrieri's painterly and sexual potency even torments him on an unconscious level, for in a nightmare the younger artist sees himself desperately attempting to complete a canvas from a live model without success until Balestrieri, resembling Picasso (the archetype of the creative and virile modern painter), arrives and finishes the task. The mocking dream ends when Dino takes a knife and slashes the canvas, only to discover that he has mutilated the model and not the canvas. The sole dimension by which the younger painter can overcome his alienation from persons and objects is that of sado-masochistic aggression, and the deceased Balestrieri, who brought about his own death from the strain of making love to Cecilia, serves as that ideal "Other" to mediate Dino's desires and direct him on a course leading to an act of self-destruction. Dino's life becomes an imitation of Balestrieri's: he takes Cecilia as his mistress, spies on her, hands her money as gifts to her other lover - all in emulation of Balestrieri 
because of Dino's conviction that his resented rival 'possessed' reality in his dual role of painter and lover. ${ }^{8}$ Neither Dino nor Balestrieri have ever dwelt in the 'spiritual city' that Kandinsky in his text Concerning the Spiritual in Art sees threatened by vulgarian materialism. The confusion of eros with art never brings Dino into a self-renewing rapport with reality but carries him to the brink of annihilation.

Dino's vulgarian insensitivity consists in his viewing other persons as no more than purchasable commodities. He lives what Kandinsky calls the nightmare of materialism that turns life into an evil, senseless game. The great extent to which Moravia's protagonist plays that game becomes evident in a scene where Dino attempts to reduce the elusive Cecilia to an object of economic exchange. He has taken the young woman to his mother's villa to introduce her as his fiancée. While his mother is downstairs entertaining guests at an evening party, Dino leads Cecilia to the mother's bedroom where the girl herself offers to make love as a friendly gesture before she leaves on a vacation trip with her other lover. Enraged because he cannot establish definite boundaries to Cecilia's unseizable personality, Dino makes a final effort to capture her reality. He places the naked girl on his mother's bed and covers her with banknotes and stock certificates from his mother's safe, all the while promising Cecilia the money if she agrees not to go on the holiday. Moravia elevates this scene of the artist as vulgarian materialist to a psychomythic dimension by describing a Titianesque painting of Danae and the shower of gold which hangs over the bed, for the golden shower of Jupiter's erotic penetration is depicted as a rain of brightly shining coins. The painting appears here as an ironic, mythic transformation of the economic-sexual exchange that Dino would like to effect with the banknotes. The gods seem to share the insincerity and possessiveness of mortals as the mythic painting summarizes, symbolizes and makes eternal the reduction of humans to marketable items. But as Dino is constantly forced to acknowledge, humans are objects with a. will that can refuse. When Cecilia rejects his offer, the Italian painter reacts with characteristic violence and almost kills the young woman, since by depriving her of life he might at last secure possession of her being. As always Dino has failed to reach Kandinsky's "inner reality." His imitation of Balestrieri has not brought him the divine omnipotence of a Jupiter, for all Dino did was to counterfeit the outer form of the older painter's fatal pursuit of the enigmatic reality incarnated by Cecilia. The vulgarian materialist can never purchase the "spirit- 
ual beyond" which Kandinsky declares to be the goal of an authentic artist.

What is lacking in both Dino and Balestrieri is the inner element of genuine emotion that Kandinsky in Concerning the Spiritual in Art states will effect a spiritual revolution. Art for the young Kandinsky, influenced by the theosophical writings of Rudolph Steiner and Mme Blavatsky, holds an awakening, prophetic power. The artist's task is to demonstrate a certain movement of cognition toward cosmic awareness. A painter best communicates his quest for inner knowledge through abstraction which reconstructs reality. To escape the nightmare of materialism a painter must abandon representation, thus freeing himself from the material obstacles to his forming a viable relationship with the universe. In order to know cosmic laws and resist materialistic temptation an artist has to return to the simplicity of primitive peoples and regain a naive sense of oneness with the world. The artist's soul will vibrate in spiritual harmony with reality after emerging from a period of trial and suffering. Dino and Balestrieri are examples of painters who scatter their artistic strength into emptiness, failing to pay attention to the "inner sound" of inspiration and instead trying to win possession through their art. No one for Kandinsky can possess reality; the artist as prophet contemplates reality in its loftiest dimensions.

Painting as it appears in Moravia's novel would be classified by Kandinsky as "barren art" that at best reflects the possessive soul of artists like Dino and Balestrieri who cannot see beyond the outer form of reality. The inner life of the true artist must inter-act with the cosmos, and neither technique nor professional success can bring an artist into contact with the authentic, secret soul of the universe. That "potenza" which is missing in the Moravian protagonist is the special vision that permits an artist to perceive inner reality and penetrate cosmic mysteries. Rather than displaying emptiness or academic formalism, the canvases of the genuine artist will convey a message of struggle and triumph: "In every painting a whole life is mysteriously enclosed, a whole life of tortures, doubts, of hours of enthusiasm and inspiration." 9 Only then will the completed canvas have something worthwhile to communicate as the artist adapts form to internal significance. For Kandinsky the generation of a work of art remains a mystery that aesthetic theories and schools of painting style can never fully explain. The authentic artist listens to the voice of the inner soul and learns the proper form to follow. Barren artists like Dino and Balestrieri are incapable of creating works of beauty since 
their souls are insensitive to the spiritual dimensions of reality: "That is beautiful which is produced by internal necessity, as only that which springs from the soul can be beautiful" (p. 75). Painting for Kandinsky is a sacred function, and its practitioners resemble priests who worship and mediate the spiritual and beautiful through their works. By contrast Dino and Balestrieri profane their vocation since their canvases do not reflect that spiritual atmosphere which for the Russian painter is the outer expression of a true artist's dedication to revealing cosmic reality.

Renunciation of art is Dino's way of acknowledging that he never appreciated the message of Kandinsky's empty canvas awaiting the responsible painter who would achieve a harmonious composition of pure form and color. The soul of the Moravian protagonist is disharmonious, off-key, totally removed from either the simple melodic compositions or the complex polyphony in the canvases of the Russian artist. Kandinsky succeeded in surmounting the challenge of the object by envisioning a universe where abstract figures replace objects across the landscape of the creative soul. Dino always remains inarticulate, most vividly expressing himself through violent gesture while the Russian painter fashioned a grammar of visual language to organize singing colors and restraining lines in patterns of significance. By alternating the cold serenity of horizontal lines and the warm thrust of verticals as well as weaving a texture of points Kandinsky sought to objectify a purely subjective world drawn from his creative imagination. ${ }^{10}$ Yellow triangles, blue circles and red squares counted among the elements which brought harmony to the chaotic storm of sounds in the canvases of the Russian painter. Dino knows only the chaos, not understanding that harmony rests on the principle of contrast. Although Kandinsky himself constantly strove to free himself of every tie to objects, the Russian painter recognized that other artists before him had succeeded in producing authentic works by means of the object. Cezanne, in Kandinsky's evaluation, knew how to fashion life out of a teacup by seeking to reach the inner vitality of inanimate objects through comprehension of color, geometric form and volume. Unlike Cezanne, Moravia's protagonist deprives animate beings of life as he attempts to reduce others to the status of manipulatable objects. Abstract painting for Dino has resulted as no more than the negation of art which is always a journey of discovery and not a flight from reality. ${ }^{11}$

Unable to sustain the illusion of ever possessing reality in the form of a person or object, the Moravian protagonist resorts to su- 
icide as the ultimate means of evasion. But for the first time in the Italian novel hope comes to Dino as he convalesces in a hospital after his unsuccessful attempt at suicide. Outside the window of the hospital room he beholds a cedar of Lebanon, which inspires him with a sense of joyous calm. The tree, like Kandinsky's empty canvas, is saying to Dino "Here I am!" and at last he responds in a spirit of sympathetic vibration rather than predatory possessiveness. From that tall and straight tree of biblical fame Dino learns a lesson of loving appreciation and disinterested contemplation. Through contemplation, instead of possession, he now wishes to enter into a viable relationship with the outer world of objects and persons. Once again he dreams of resuming his work as a painter, to express this new rapport with the universe. Dino also admits that all existence, as represented by Cecilia, will remain unseizable and that he must respect the separateness and autonomy of others. Moravia's novel does not conclude in a spirit of ecstatic liberation because Dino's conversion from boredom is never free from doubt. Dino expresses the aspiration to hope rather than the certitude of its attainment. The total victory of a Kandinsky in re-integrating objective reality into a realm of abstraction never comes to Dino, who trembles in hesitation before committing himself to the authentic artist's gratuitous adoration of existence. But like the Russian artist Moravia's protagonist has divined the presence of a mysterious life within objects, and in contemplating that mystery of the inescapable object the Italian painter begins to surmount alienation.

\section{Kent State University}

\section{NOTES}

1 See Paul Overy, Kandinsky: The Language of the Eye (New York: Praeger Publishers, 1969), p. 36.

2 See p. 7 of the Bompiani edition (Rome, 1960). All subsequent page references will be to this edition.

3. Moravia's arithmetic leaves something to be desired. Dino states precisely that he was born in 1920, stressing that his childhood and youth were passed under the political alienation of fascism. In 1947 he left his mother, and the present time of the narrative is supposed to be exactly ten years later. Yet, somehow, Dino manages to celebrate his thirty-fifth birthday in the course of events!

4 Kandinsky, "The Empty Canvas," in The Painter's Object, ed. Myfanwy Evans (London: Gerald Howe, Ltd., 1937), p. 53.

5 Donald Heiney, Three Italian Novelists: Moravia, Pavese, Vittorini (Ann Arbor: Univ. of Michigan Press, 1968), p. 67, over-emphasizes Moravia's distrust of experimentalism as shown in a review of a modernist exhibition in Verona. In La noia it is Dino's evasive recourse to abstractionism rather than abstractionism itself that is criticized. 
6 Quoted by Heinz Werner, Comparative Psychology of Mental Development (New York: Follett Publishing Co., 1948), p. 71.

7 Ibid., pp. 67-82, defines and illustrates physiognomic perception.

8 Edoardo Sanguineti, Alberto Moravia (Milan: Mursia, 1962), pp. 123-24, analyzes Dino's fatal imitatio of Balestrieri. The painter enters into a second triangular relationship with Cecilia and her other lover, the unemployed actor Luciani.

9 Kandinsky, Concerning the Spiritual in Art and Painting in Particular, trans. and rev. Sadleir, Golffing, Harrison, and Osertag (New York: George Wittenborn, Inc., 1947), p. 25. Subsequent page reference will be to this edition.

$10 \mathrm{Cf}$. Overy, pp. 77ff.

11 A pioneering study on the influence of Kandinsky's art theories upon the formation of Moravia's protagonist in La noia can be found in Donald Nesti, "Kandinsky and Moravia," Le Ragioni Critiche, 6, Nos. 19-20 (January-June 1976), 25-35. 